\title{
TEACHER'S STRATEGIES TO CREATE A CONDUCIVE LEARNING ENVIRONMENT IN THE RON CLARK STORY MOVIE
}

\author{
a Adi Yusuf, b Ernawati Pattisahusiwa \\ ${ }^{a, b}$ Universitas Pesantren Tinggi Darul Ulum \\ e-mail: adiyusuf@fbs.unipdu.ac.id
}

\begin{abstract}
In learning process, a good teacher indeed needs a strategy to create a conducive learning environment in order that it runs smoothly. The Ron Clark Story Movie depicts how a teacher uses various strategies to create a conducive classroom environment so that the learning process can run well. The purposes of this research are to identify what strategies used by the teacher, Mr. Clark, to create a conducive learning environment in The Ron Clark Story Movie and to describe how the strategies are implemented by the teacher to create a condusive learning environment in the Movie. This study was designed qualitatively. The data of this study were scenes on the teacher's strategies to create a conducive learning environment in the movie. The source of data in this study was a movie entitled The Ron Clark Story.It was found that Mr. Clark used 5 types of teacher's strategies to create a conducive classroom environment: physical design of the classroom, rules and routines, relationship, engaging and motivation, and discipline. Each of the strategies has several classifications. By applying these strategies, the students of $\mathrm{Mr}$. Clark finally succeeded in passing the exam with satisfactory grades.
\end{abstract}

Keywords: Conducive Classroom Environment, Teacher's Strategy, The Ron Clark Story Movie. 


\section{INTRODUCTION}

Teachers are very influential in the learning process. They play an important role in helping students to develop the learning process, and to realize students' goals (Mulyasa, 2005, p.35). The students have different experiences, backgrounds, and abilities. Therefore, the teacher is expected to be able to provide what the students' need with all these differences.

Teachers need to create a conducive learning environment that a comfortable, safe and enjoyable atmosphere for the students' in order to make them understand what is being learnt. It will help the teacher and the students in the learning process. The students will be easy to understand the lesson taught by the teacher, because the understanding of the students is the purpose of the learning process (Khasanah, 2014, p.89).

Teachers must have various abilities to make the learning process run smoothly. Not only the teachers must has the academic abilitiy but also they must have the ability to motivate the students to join the learning process well.

Understanding the students' characteristic is one of the ways to create a conducive learning environment by the teacher in social relations with the students. It is important to conduct in order to create a good relationship with the students. Establishing relationships will help build mutual respect, and minimize the problem of students' misbehaviour (Partin, 2012, p.15). Therefore, the teacher can choose the right strategy to teach the students.

Although the understanding of students' characteristics is one of the best ways to create a condusive learning invornment, but the teacher may find many difficulties in the classroom when he has a lot of students. Many teachers take a long time to learn the students' characters, and they must always be patient to the impish students at the same time. It is the responsibility of the teacher to overcome them. Structuring a conducive learning environment influences student's participation and supports the teacher in the learning process, (Winataputra, 2003, p.16). Therefore, the teacher should understand the students well, and the teacher should be able to find the right strategy to manage every problem. Thus, the problems in the learning process can be resolved by the teacher.

In The Ron Clark Story movie, presents a teacher who is able to manage the problematic classroom atmosphere to be conducive. The problems that often arise usually interfere learning activities in the classroom. For instance, the students make a fuss by themselves, leave their seats without permission, and joke with other friends. In this case, the teacher in this movie used the strategies to create a conducive learning environment by made some rules. In this movie, Mr.Clark as the teacher made the rule such as respect each others. For example, Mr. Clark explained to his students how to be polite to him by calling the name as "Sir". He said for his students' that "If you are asked a question, ..... you will say," yes, sir, ".... or, no, sir. ... not, "yep," "nope," "uhuh," "nuh-uh". Another example of this movie is he made a concept of thought for his student. He said for his students' that all the people in his class are a family. He made a writing on the classroom wall that read "We are Family". The rules that he made are strategies for creating a conducive learning environment in order to make the learning process run well.

This research is hoped to contribute to the development of learning process, especially in creating good classroom condition, and explaining the teacher strategies in creating a conducive learning environment. This research is expected that it can be a teacher's reference in overcoming the problematic classroom conditions to be 
conducive in order to the teacher and the students can join the learning process optimally.

\section{RESEARCH METHOD}

In this research the researcher conducted a qualitative research. Cresswell, J. (1998) notes that qualitative research is a type of research that results in findings that cannot be achieved using statistical procedures or other means of quantification or measurement (p.24). Furthermore, Cresswell (2003) cited in Yusuf (2012) points out that the data of qualitative research are collected in the form of "texts (or words) and images or pictures data" (p.45). Since this was a qualitative research, this research described the results i.e. what strategies applied by the teacher to create a conducive learning environment and how they are implemented in words. The theory on types of strategies to create a conducive learning environment proposed by Brophy (2006) was used to analyze the data.

\section{Data and Source of Data}

The data of this study were scenes on the teacher's strategies to create a conducive learning environment in the movie. The source of data in this study was a movie entitled The Ron Clark Story.

\section{Technique of Data Collection}

Technique of collecting the data was the way to get or gather the data to be analyzed later. According to Ary et al., (2006) there are some methods that used to collect the data in qualitative research. They are observation, interview, and document analysis. In addition, Ary et al. (2006) states that observation is a basic method for obtaining data in a qualitative research.

In this study, to gather the data, the researcher used an observation sheet as a research instrument. By using the observation sheet, the reasearcher identified what strategies were used by the teacher to create a conducive learning and how he applied the strategies in the movie.

\section{Steps of Data Collection}

There were some steps to collect the data. Firstly, watching the movie several times. This was done in order that the researcher understood well the plot of the story in the movie. Secondly, reading the scenes. Thirdly, Identifying the teacher's strategies to create a conducive environment. Lastly, note-taking the scenes containing the strategies.

\section{Technique of Data Analysis}

\section{Classifying}

After the data were collected, classification was conducted. The classification was done based on five types to create a conducive learning environment as proposed by Brophy (2006). They were physical design of the classroom, rules and routines, relationships, engaging and motivating instruction, and discipline. 
2. Describing the data

After obtaining adequate data, the analysis of the teacher strategies to create a conducive environment that occurred in the movie was described first. After that, the researcher described how the teacher implemented the strategies to create a conducive learning environment.

3. Concluding

After describing the data, the researcher concluded the result of analysis which was mainly focused on what strategies and how they were conducted by the teacher to create a conducive learning environment in that movie.

\section{FINDINGS AND DISCUSSION}

Based on the observation, the researcher could find the teacher's strategies and display a table of findings from the objects discussed. Then, the findings would be explained in discussion section.

\section{FINDINGS}

\section{An Identification Teacher's Strategy to Create a Conducive Learning Environment in the Movie.}

The table below presents five types of teacher strategies. Of the five types of teacher strategies, there were several classifications identified used by Mr. Clark.

Table 4.1 The identification of teacher's strategies

\begin{tabular}{|c|c|c|c|c|c|}
\hline No. & Teacher's Strategies & Classification & Yes & No & Minutes \\
\hline \multirow[t]{3}{*}{1} & \multirow{3}{*}{$\begin{array}{l}\text { Physical design of the } \\
\text { classroom: }\end{array}$} & - Seating arragenent & $\mathrm{Y}$ & & $47: 08$ \\
\hline & & - comfortable & $\mathrm{Y}$ & & $44: 22$ \\
\hline & & - cleanly & $\mathrm{Y}$ & & 18:55 \\
\hline \multirow[t]{2}{*}{2} & \multirow[t]{2}{*}{ Rules and routine } & - Be polite & $\mathrm{Y}$ & & $22: 26$ \\
\hline & & - Respect with the other & $\mathrm{Y}$ & & 22:17 \\
\hline \multirow[t]{3}{*}{3} & \multirow[t]{3}{*}{ Relationship: } & - Give motivation & $\mathrm{Y}$ & & $44: 15$ \\
\hline & & - Respect others right to speak & \multirow{2}{*}{\multicolumn{2}{|c|}{$\mathrm{N}$}} & \\
\hline & & $\begin{array}{l}\text { - Individual approach to each } \\
\text { students }\end{array}$ & & & $\begin{array}{l}51: 18 \\
52: 34 \\
55: 08\end{array}$ \\
\hline \multirow[t]{2}{*}{4} & \multirow[t]{2}{*}{$\begin{array}{l}\text { Engaging and } \\
\text { motivation: }\end{array}$} & $\begin{array}{l}\text { - There are rules at the begining } \\
\text { of learning that must be aggred } \\
\text { between the teacher and students. }\end{array}$ & $\mathrm{Y}$ & & $21: 56$ \\
\hline & & $\begin{array}{l}\text { - Combination subject matter with } \\
\text { music, card games, audio visual, } \\
\text { and etc. }\end{array}$ & Y & & 48:19 \\
\hline \multirow[t]{2}{*}{5} & \multirow[t]{2}{*}{ Dicipline: } & - Enter and exit the class quietly & $\mathrm{Y}$ & & $22: 50$ \\
\hline & & $\begin{array}{l}\text { - Form a line to enter and exit } \\
\text { class }\end{array}$ & $\mathrm{Y}$ & & 26:01 \\
\hline
\end{tabular}




\section{The Description of the Teacher's Strategies Appear in the Movie}

In The Ron Clark Story Movie, there were five types of teacher's strategies to create a conducive learning environtment based on the theory proposed by Brophy (2006). They were Physical design of the classroom, Rules and routines, Relationships, Engaging and Motivation, and Discipline. It can be seen in the explanation below.

\section{Physical design of the classroom}

In this strategy, there were three classifications such as Seating arragenent, Comfortable, and Cleanly. The first classification was The Seating Arragenent at 47.08 minutes, Mr. Clark arranged the seating of his students with the U-shaped seat model. Since, it was adapted to the teaching methods being applied by Mr. Clark in the film. At that time, he was teaching how to memorize the names of American presidents by using songs. With the U-shaped seat model, all students could participate because the classroom became wider in the middle and front.

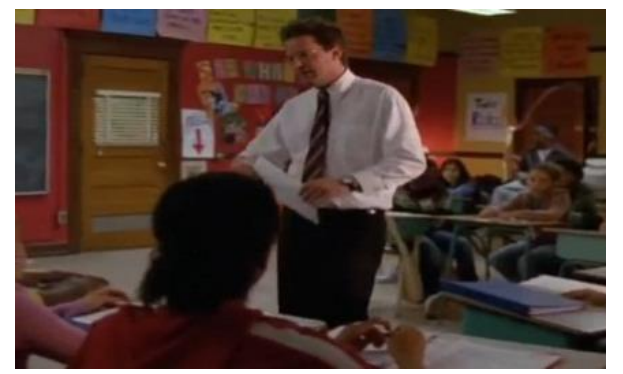

Picture 4. 1: Mr.Clark made The U-Shape Seat Model

The second classification was Comfortable at 44.22 minutes, Mr. Clark made a comfortable atmosphere for the class while he was giving motivation to his students. He created a calm atmosphere in the classroom by dimming the lights and presenting a birthday cake that was filled with candles as a symbol of a new desire to get a good learning outcomes.

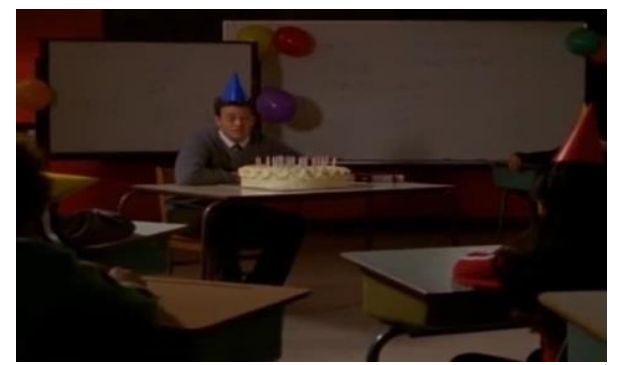

Picture 4. 2: Mr.Clark was giving motivation for his students'

The last classification of this strategy done by the teacher was Cleanly at 18.55 minutes. Mr.Clark as a new teacher at that time decorated his class with beautiful paint. He also presented his class with several computer units. All of these things were aimed to increase students' enthusiasm for learning. 

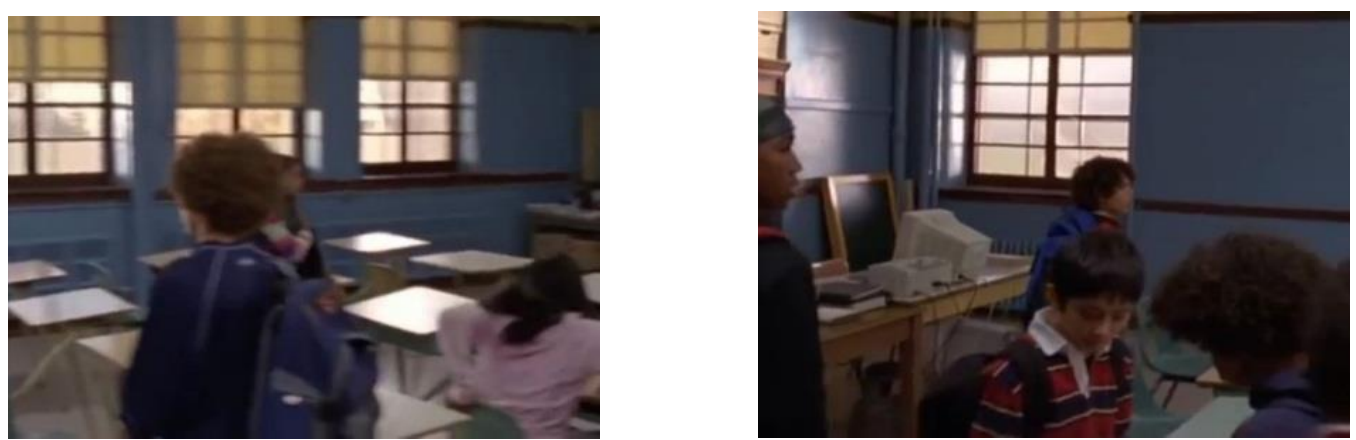

Picture 4. 3: The Student were surprised by their new decoration of the classroom

\section{Rules and Routine}

There were two classifications in this strategy. They were Be polite, and Respect with the other. The first classification of this strategy was Be Polite at 22.26 minutes, Mr. Clark explained to his students how to be polite to him by calling the nickname to their teacher. As the following conversation at 22:26 to 22:34 minutes "If you are asked a question, ..... you will say," yes, sir, ".... or, no, sir. ... not, "yep," "nope," "uh-uh," "nuh-uh".

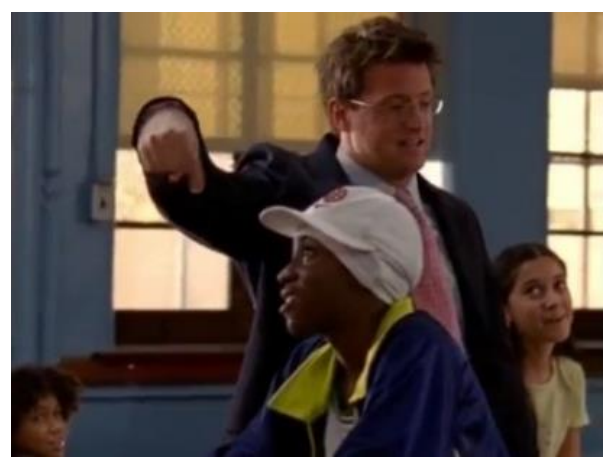

Picture 4. 4: Mr.Clark was explaining to his students' how to be polite to him

The last classification of Rule and Routine strategy was Respect with the other. It occured in this movie at 22.17 minutes. Mr. Clark explained his students the rule number two in his class about respecting others. He said "Rule number 2 ... we respect each other. Hey, you will call me Sir... Not man, not dawg, not fool".

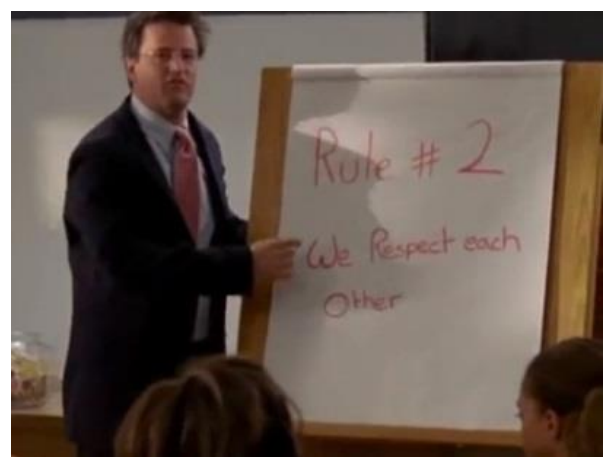

Picture 4. 5: Mr.Clark showed the rule number 2 for his students' 


\section{Relationship}

The Relationship strategy had three classifications such as Give motivation, Respect others right to speack, and Indiviual approach to the students. There were only two classifications in the movie. They were Give motivation and Indiviual approach to the students.

Give motivation occured at 45.49 and 01.07.55 minutes. At 45.49, Mr. Clark motivated his students to start this year with team work as well as possible in order to get good exam results. The following was a story told by Mr. Clark to give them motivation, it could be seen at 44:15 to $45: 43$ "I always wanted to go rock climbing. But there I was, on the edge of this cliff, ropes on me, and my friends are yelling, "jump, jump, jump!"And I looked down ....and it is a long way down. So, I'm on the cliffand. I'm yelling,"I can't, I can't, I can't. "And my friends are yelling,"yes, you can. You can do it! Jump! Jump! Jump! "And I did. I thought I was going to die, but when I jumped out, it felt like I was flying. I did something that I never thought I could do. And it was pretty cool". Now you guys may not know this, but in this classroom we're rock climbing every day. We are climbing up and up and up. And we are there, and now it's time to jump. I know you're scared. But I want you to do it. I want you to jump. I want you guys to feel what it's like ...to fly. So, I want each of you to come up here, and light one of these candles. Ok, come on up, guys. And when you light a candle ...it symbolizes that we are joined together. And if you trust me ... you can learn more than you ever dreamed of, and that's a promise.

Individual approach to the student occured at some scanes in this movie. Firstly, at 51:18 minutes Mr. Clark visited Tayshawn Mitchell to submit the results of his test with satisfactory scores, and also wanted to buy him meal. Mr.Clark paid more attention to him because he was a clever student but had a criminal environment. Mr.Clark wanted him to focus on learning and abandon his bad behavior.

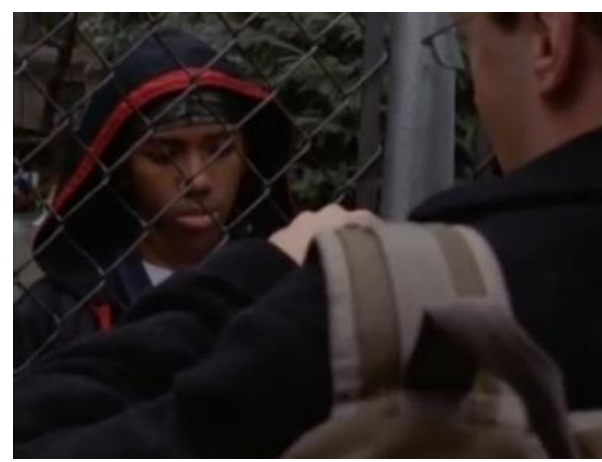

Picture 4. 6: Mr.Clark visited Tayshwn Mitchell

The second example of Individual approach to the student in this movie occured at 52.34 minutes. Julio Vasquez, who was one of Mr. Clark's students often committed misbehavior by stealing and gambling. Mr. Clark invited him to a restaurant to play cards that it was Julio's hobby while studying leisurely. 


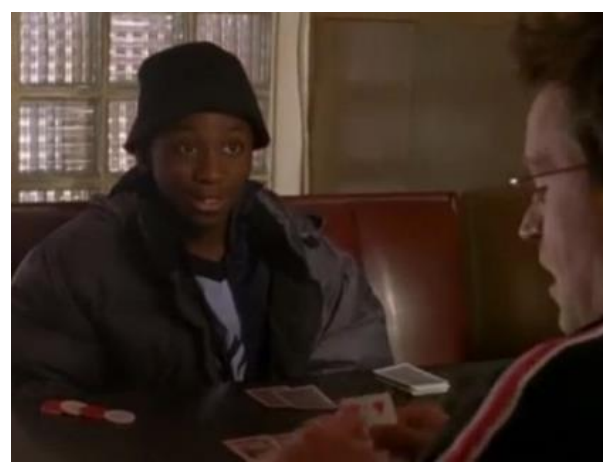

Picture 4. 7: Mr.Clark met Jolio Vasquez at the restaurant

Last example of this classification occured at 55.08 in this movie. Mr. Clark met Shameika Wallace, an intelligent student who was busy looking after her younger siblings at home when her mother went to work. Shameika had difficulty in studying if she had to keep busy looking after her younger siblings. So, Mr. Clark as her teacher came to her house to help her to study well. Mr. Clark was cooking, and looking after her younger siblings in order that Shameika could focus on her study.

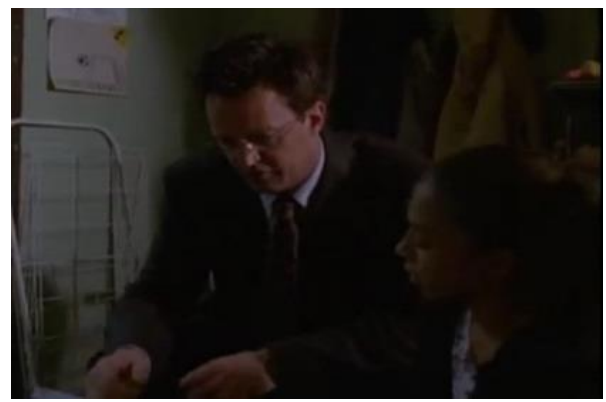

Picture 4. 8: Mr.Clark visited Shameika Wallace

\section{Engaging and Motivation}

There were two classifications in this strategy. Firstly, There are Rules at the Begining of Learning that must be Aggred Between the Teacher and Students. The rule, such as Be Polite was one of the Rules and Routine classification strategy implemented by Mr. Clark to respect the and to respond to the teacher's words. It was found at 21.56 minutes when Mr.Clark explained all his rules at the first day of meeting with his students in the class.

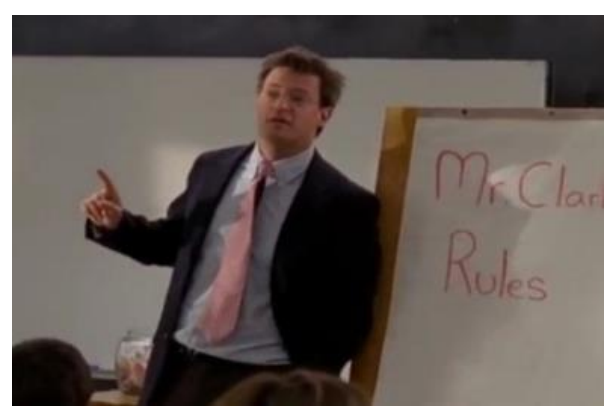

Picture 4. 9: Mr.Clark was explaining his rules at the first time met his students'

Secondly, Combination Subject Matter with Music, Card Games, Audio Visual, and Etc. It was the classification of Engaging and motivation strategy that occured at 48.19 minutes in this movie. Mr. Clark as a creative teacher teached how to memorized 
the names of American presidents in a fun way. He made a song containing the names of American presidents and nicknames. Then sang it with the rhythm of the music from the loudspeakers. His students enthusiastically followed the way he taught.

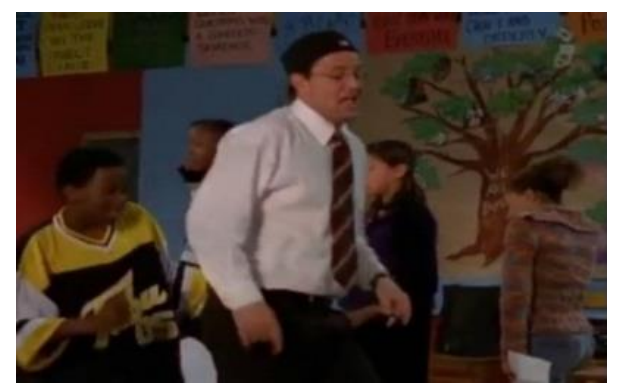

Picture 4. 10: Mr.Clark and his student were singing and dancing together while memorizing the names of American presidents

\section{Discipline}

There were two classifications in this strategy. They were Enter and exit the class quietly, and A line to enter and exit class. Firstly, Enter and exit the class quietly occured at 22.50 minutes. In the movie, Mr Clark showed the third rule, and explained it to his students. He said that "Rule number 3 we will form a line to enter and exit class". Since the students were very disorganized when they entered or left the classroom. therefore, Mr. Clark made this rule.

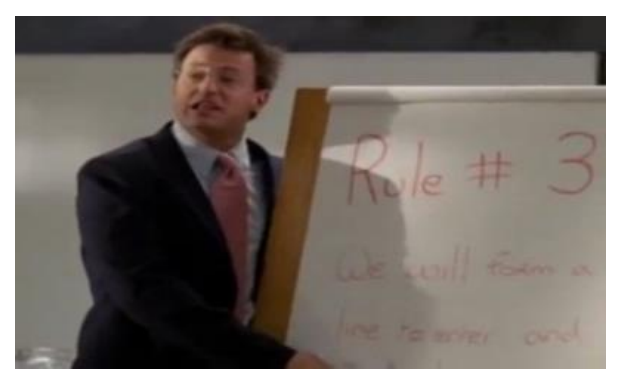

Picture 4. 11: Mr.Clark showed the rule number 3 for his students'

Other classification in this strategy was A line to enter and exit class. It occured at 26.01 minutes. Mr. Clark taught his students' to be discipline in walking in the school. They were walking in line when going to the canteen. They had to be in the line and they had not to be cutted the line. Mr. Clark gave both rules in order that his students were discipline while at the school.

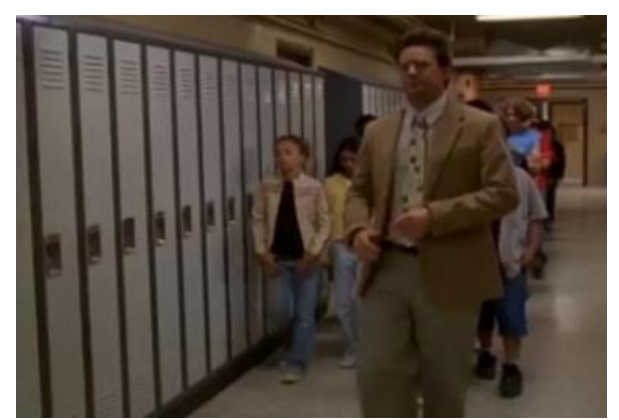

Picture 4. 12: Mr.Clark was teaching how to walk in a neat line 


\section{DISCUSSION}

It has been found that they were five types of teacher strategies implemented by Mr. Clark in creating a conducive classroom environment. From each of these strategies, there were also several classifications. The findings were discussed sequentially with the classification of each teacher's strategy implemented by $\mathrm{Mr}$. Clark in the film from beginning to end.

On the first day of teaching in his class, Mr. Clark implemented Cleanly which was a strategy of the Physical Design of the Classroom. He did it with the hope that his students would see the class being clean and eager to join the lesson. His students were surprised by their neat class when they entered Mr. Clark's first class. After that, Mr. Clark began learning by implementing There are Rules at the Begining of Learning that must be Aggregated Between the Teacher And Students. it was one of the classifications of the Engaging and Motivation strategy. He explained all the rules he made to his students while he was teaching them. Like it or not, his students had to obey the rules. One of the rules was Be Polite. it was one of the Rules and Routine classification strategy implemented by Mr. Clark. He asked them to respect his teacher from the way they responded to his teacher's words. Then, Mr. Clark implemented Respect with the Other. It was also one of the Rules and Routines strategies. He explained to his students to call the teacher's name in a good name, and not a bad name. Both classifications were taught to them so that they had good qualities that can respected the teacher who taught them.

Mr. Clark also implemented Enter and exit the class quietly as one of the rules he made. it was a part of the Dicipline strategy. He explained rule number three for them to be calm when entering class or leaving class. Then, he implemented $A$ Line to Enter and Exit Class. This was also a classification of the Decipline strategy. He taught and watched them while walking inside the school. They had to walk in the line and they had to not cut the line. Both classifications were implemented in order to make the students discipline.

At the beginning Mr. Clark delivered the rules, but some of his students disobeyed, but gradually they also obeyed the rules. Mr. Clark's first strategies in creating a conducive classroom environment were successfully implemented to his students. Finally, they began to be close with Mr. Clark

When Mr. Clark was close to his new students, he implemented Give Motivation. That was one of the Relationship classification strategies. Mr. Clark adopted the strategy to motivate his students not to give up. He motivated them very creatively. Since, Mr. Clark implemented Comfortable. It was part of the Physical Design of the Classromm strategy when he motivated his students. He had decorated the classroom to be more calm and presented a cake with a candle on it. Then, Mr. Clark asked them to blow out the candles. As a sign of striving for success together. It was implemented by Mr. Clark so that his students had a strong courage in facing the coming exam. With the implementation of the two strategies, his students also had the courage and high confidence in taking lessons for exams.

As a creative teacher, Mr. Clark implemented Seating Arragement. It was part of the Physical Design of the Classromm strategy and implemented Combination of subject matter with music, card games, audio visuals, etc. It was part of the Engaging and motivation strategy. Both of them were implemented when he taught them to memorize the names of American presidents. Mr. Clark made the students' seats Ushaped so the classroom would be wider in the middle and front. Then, He invited them to come forward to the class to join memorizing the names of American 
presidents with the accompaniment of music and dance. It made them very eager when memorizing it.

Finally, Mr. Clark implemented the Individual approach to each student, it was the Relationship classfication strategy. He implemented it to his three students. They were Tayshawn Mitchell, Julio Vasquez, and Shameika Wallace. They were smart students but had problems outside the school. So, Mr. Clark approached them to help them focus on their education in order that they got satisfactory grades in the exam. With this implemented strategy, the three students became more focused on their study.

As it was known that the arrangement of a conducive learning environment influences student participation and supports the teacher in the learning process, (Winataputra, 2003, p.16). That was implemented by Mr. Clark as a professional teacher in creating a conducive classroom environment. Until the success of his students in facing the exam. All students successfully passed the final exam. Even their class got the highest score in their city.

\section{CONCLUSION}

The Ron Clark Story movie presents how a teacher educated his students well. Mr. Clark, who as the teacher in the film, has succeeded in creating a conducive classroom environment in a class he has just handled. Of course it can not be separated from the selection using teacher strategies that were right for their students.

Based on the result of disscusion, it can be concluded that the teacher used some strategies to create conducive learning environment. The teacher strategies done by Mr. Clark such as Physical disign classroom, Rules and routine, Relationship, Engaging and motivation, and Dicipline. Each strategy used was adapted to the conditions of the students and their environment. With the variety of teacher strategies used by Mr. Clark in the right situation for his students, he had successfully educated them as evidenced by his students' very satisfying test results.

\section{SUGGESTION}

The teacher strategy used by Mr. Clark in creating a conducive classroom environment is certainly very inspiring for viewers of The Ron Clark Story movie or readers of this study. Therefore, the researcher intend to provide suggestions that may be useful for the readers of this study.

The educators need many creative ways to create a conducive classroom environment. Therefore, this research is expected to be a useful contribution for them in creating or developing teacher strategies to control classroom environment in order to the learning process can run smoothly. In addition, This research is also expected to be a useful reference for further research both by the author or other researchers. Of course, there are still gaps that can be taken from this study about teacher strategy. Moreover, The Ron Clark Story movie can also be analyzed for further research with other discussions. 


\section{REFERENCES}

Ary, D ., Jacobs, L.C., \& Sorencen, C. (2006). Introduction to research in education. Wadsworth Thomson.

Brown, D. H. (2001). Teaching by principles : An Interactive Approach to Language Pedagogy. New York : Addison Wesley Longman.

Brophy, J. E. (2006). History of research in classroom management. In C. Evertson \& C. Weinstein (Eds.), Handbook of Classroom Management: Research, practice, and contemporary issues (pp. 17-43). Mahwah, NJ: Lawrence Erlbaum Associates, Inc.

Cresswell, J. W. (1998) . Qualitative Inquiry and Research Design: Choosing among Five Tradition. London: Sage Publications.

Cresswell, J. W. (2003). Research Design Qualitative, Quantitative and Mixed Approaches. USA: SAGE Publications, Inc.

Muljani. A. N. (1983). Administrasi Pendidikan Di Sekolah. Yogyakarta: IKIP C. Wragg. 1987. Pengelolaan Kelas. Pent: Aswan Jasin. Jakarta: Grasindo.

Mulyasa. (2005). Menjadi guru, menciptakan pelajaran kreatif dan menyenangkan. Bandung: Remaja Rosdakarya.

Khasanah, N. U. (2014) Pengaruh metode mengajar dan media pembelajaran terhadap motivasi belajar siswa. Yogyakarta : Universitas Negeri Yogyakarta

Partin, R. L. (2012). Kiat nyaman mengajar di dalam kelas: strategi praktis, teknik manajemen dan bahan pengajaran yang dapat diproduksi ulang bagi para guru baru maupun guru berpengalaman. Jakarta: Indeks.

Winataputra, U. S. (2003). Strategi belajar mengajar. Jakarta : Universitas Terbuka

Wikipedia, (2019). Plot of the ron clark story movie. Retrieved from https://greycaps.com/theteacher/Recommendation/Theronclarkstory

Yusuf, A. 2012.Grammatical Overgeneralization Made by Level 1 Learners of Firdaus English Course (FEC) Patianrowo Nganjuk. Vol. 1 No. 1, June 2012. 